\title{
Citizens in Policing: The lived reality of being a Police Support Volunteer
}

\author{
Andrew Millie \\ Published as: \\ Millie, A. (2018) 'Citizens in policing: The lived reality of being a Police Support \\ Volunteer', Policing and Society, DOI: 10.1080/10439463.2018.1451529
}

\begin{abstract}
The focus for this article is the Police Support Volunteer (PSV), a brand of non-warranted and usually non-uniformed volunteer that was introduced in England and Wales from the 1990s onwards. The article draws on participatory action research with PSVs in Lancashire Constabulary. The background to greater use of volunteers within policing is discussed with particular reference to the political projects of austerity and responsibilisation - the later involving calls for citizens to take greater responsibility for their own safety and security. In these contexts the article considers volunteers' motivations, skills and deployment. The article focuses particularly on the lived reality of being a PSV, including the assumed role of PSVs within the wider police family. A subordinate relationship with other paid colleagues within the police family is challenged. The effective use of PSVs is discussed, including the introduction of police powers for volunteers with the 2017 Policing and Crime Act. Implications for our understanding of policing, and for the future of non-warranted volunteers, are discussed.
\end{abstract}

\section{Keywords:}

Police Support Volunteer; volunteers; responsibilisation; police powers

\section{Introduction}

Academic attention on policing focuses primarily on the activities of paid, warranted and uniformed officers. This is unsurprising given the historical and contemporary dominance of paid professional police officers. Yet, there is also a long history of volunteer involvement in the police. In the UK this has been chiefly in the form of warranted and uniformed special constables who, from the eighteenth century onwards, have acted as voluntary police officers (Leon, 1991; 2018). Whilst a long way from their peak of 130,000 during World War Two, by March 2016 there were around 16,000 special constables operating in England and Wales (Heike, 2018). In recent years there has been also an expansion in opportunities for nonwarranted volunteers across many aspects of police work. According to College of Policing estimates, there are approximately half a million volunteers working with or for the police in England and Wales under what has been badged the Citizens in Policing programme (College of Policing, undated, a). This estimate includes warranted special constables, but also nonwarranted volunteers - including young people engaged as Volunteer Police Cadets, those 
who are active as part of Neighbourhood and Home Watch, and other volunteers that have become known as 'Police Support Volunteers' (PSVs).

This article focuses on non-warranted - and usually non-uniformed - PSVs. According to the College of Policing (undated, a):

Police Support Volunteers are now part of the police culture and are highly valued not only for the direct support they provide but for the key links to the community. They are vetted and undertake many varied tasks depending upon the needs and constraints of each individual force.

Whilst warranted police volunteers have received some academic attention, for example as special constables in the UK (e.g. Seth, 1961; Gill and Mawby, 1990; Leon, 1991; Millie and Jacobson, 2002; Bullock and Millie, 2018a), or as auxiliary or reserve officers, or sheriff's deputies in the US (Wolf et al., 2016; Dobrin, 2017), academic interest in non-warranted police volunteers - such as PSVs - is still in its infancy (see e.g. Britton and Callender, 2016; Millie, 2016; Bullock, 2017). This is perhaps surprising given that various forms of 'civilian policing' have been promoted for at least 30 years (Crawford and Lister, 2004) and that PSVs have been part of the wider police family in England and Wales for around twenty years (Bullock, 2014).

The article draws on research with volunteers working with Lancashire Constabulary. Research took place during 2016 and involved semi-structured interviews with 16 PSVs. A further nine special constables were interviewed as part of a broader study on volunteering, although this article draws solely on findings from the interviews with the PSVs ${ }^{1}$. Although the focus is on volunteering within one force in the North of England, the findings from this study are relevant to wider national and international contexts where volunteers are taken on to do the jobs that paid police personnel either cannot do, or do not want to do. As the study of non-warranted police volunteering in its infancy there is value in a case study approach that explores the lived reality of being a police volunteer. Future research will hopefully be able to build on this.

The article is structured around four themes. First, the background to greater use of volunteers within policing is discussed with particular focus on the political projects of austerity and responsibilisation - the later involving calls for citizens to take greater responsibility for their own safety and security. In these contexts the second aim of the article is to consider the motivations volunteers have, the skills they bring with them, as well as what volunteers actually do once signed up to becoming a PSV. Third, the article considers the lived reality of being a PSV, including the assumed role of PSVs within the wider police family, and volunteers' views on uniformed and other colleagues. And fourth, the effective use of PSVs is discussed, including whether such non-warranted and non-uniformed volunteers should ever have any police powers. This last consideration is especially important in the context of the 2017 Policing and Crime Act that allowed chief officers to designate certain powers to volunteers. The implications for our understanding of policing, and for the future of non-warranted volunteers, are discussed. 


\section{Background}

Police research has concluded that police officers have often a marginal role in social control and crime prevention (Banton, 1964; Brodeur, 2010; Crawford, 2014), with other actors able to have as much, if not more, of an impact. As Crawford (2014: 173) contends: "policing can no longer (if ever it could) be conceived as simply 'what the police do'. This necessitates an acknowledgement of, and political engagement with, the mixed economy of policing". Research on citizens' involvement with or for the police is therefore highly valuable, whether this is more formal volunteering as a special constable, other forms of volunteering with the police (such as being a PSV), or more informal voluntary actions or associations. Early incarnations of non-warranted volunteering came in the form of various Neighbourhood and Home Watch schemes, imported from the US and implemented in the UK from the 1980s onwards (Washnis, 1976; Bennett, 1990). These were examples of volunteering at a distance, where citizens volunteered their time and efforts to improve community safety where they lived. Neighbourhood and other Watch volunteers have links with the police but are not formally volunteering for the police. In the 1990s volunteering opportunities started to expand, with volunteers more formally taking up roles with the police, including volunteering to staff police station front counters that had been threatened with closure (Millie, 2012) and, in some areas, involvement in voluntary patrol (Crawford and Lister, 2004). It was at this time that the label of PSV first emerged (Bullock, 2014) to cover the activities of such nonwarranted, and (usually) non-uniformed volunteers for the police.

Fast forward to today and the context is a police service that has had to work on reduced budgets. Following the global financial crisis of 2007/2008 and a record budget deficit, the Conservative-led coalition government's 2010 spending review (HM Treasury, 2010) marked a major shift in fiscal policy and public spending resulting in a period of austerity. The effect on the police was a 20 per cent cut in government funding by 2014-2015 (Millie, 2013). For many forces this led to a freeze in officer recruitment.

At the same time, the government was actively promoting the assumed benefits of community participation and engagement through various localism and so-called 'Big Society' agendas (Millie and Bullock, 2012; Millie, 2013). According to the then Prime Minister David Cameron (2010) the Big Society is,

... where people, in their everyday lives, in their homes, in their neighbourhoods, in their workplace don't always turn to officials, local authorities or central government for answers to the problems they face but instead feel both free and powerful enough to help themselves and their own communities ${ }^{2}$.

The approach was reminiscent of earlier New Labour strategies - what Garland (2001) labelled as 'responsibilisation':

The state's new strategy is not to command and control but rather to persuade and align, to organize, to ensure that other actors play their part. Property owners, 
residents, retailers, manufacturers, town planners, school authorities, transport managers, employers, parents, individual citizens . . . must all be made to recognise that they have a responsibility (Garland 2001: 126).

The Conservatives promoted 'government at a distance' - or to use their language, a 'big society' rather than a 'big government' (Bennett, 2008; Millie, 2011). Expanded volunteering within policing appealed to this responsibilisation agenda with citizens expected to take on greater responsibility for social control and crime prevention. In this context there has been parallel growth in volunteering across other criminal justice sectors, what Tomczak (2016) refers to as the penal voluntary sector (see also Neuberger, 2009). Greater use of volunteers within policing also, of course, appealed at a time when budgets were tight and, as a result, the number of paid officers was in decline. Whilst it may be assumed that PSVs are a free resource, their recruitment, training, supervision and management, the provision of facilities, equipment, expenses and insurance mean this is clearly not the case (Brudney, 1999; Unison, 2014; Wolf et al., 2016; Bullock, 2017). That said, they are cheaper than uniformed and warranted officers and civilian staff, and there has been some concern about job-substitution (Unison, 2014).

The focus for this article is PSVs within Lancashire Constabulary. It is acknowledged that within the constabulary, and elsewhere, other volunteering opportunities have been promoted, notably through the Special Constabulary and Police Cadets. In a different force, Lincolnshire Police have introduced from 2014 a further brand of volunteers, called Voluntary Police Community Support Officers (VPCSOs) so as to provide additional visible reassurance to communities (Strudwick et al., 2017). VPCSOs wear a uniform and are a voluntary equivalent to the already existing Police Community Support Officers (PCSOs) ${ }^{3}$, although at the time of writing they have no powers, something that may change following the 2017 Policing and Crime Act.

\section{Methodology}

A Participatory Action Research approach was adopted in which PSVs from Lancashire Constabulary were involved in the co-production of research knowledge (Kindon et al., 2007). Following training by the author in semi-structured interview techniques, research ethics and analysis, four PSVs worked alongside the author as part of an interviewing team. The volunteer interviewers were recruited through an internal police advert. They were initially interviewed by the author as part of the study and then, following training, were allocated a list of other volunteers to interview themselves. The interviews took a maximum of an hour each. Interviews were recorded, transcribed and analysed for key and emerging themes. After the interviews were completed a further meeting took place between the author and three of the four PSV researchers so that they had the opportunity to reflect on their experiences and feed into the research findings. The down side of this approach is that the author had less control over some aspects of the research. However, the benefit for the research was that the volunteer-interviewers could use their own knowledge and experiences to inform further questioning. The benefit for the volunteer-interviewers was that they were able to reflect critically on their voluntary involvement with the police and gain specific 
training that may prove beneficial for their volunteering roles. All quotations used in the article are anonymised, with the respondents numbered and simply labelled as $\mathrm{F}$ for female or $\mathrm{M}$ for male. The age of those interviewed is also given.

The respondents were an opportunistic sample and were not intended to be representative of all volunteers. According to Constabulary figures for July 2016, there were 313 PSVs across the force, meaning those interviewed represented five per cent of the total. That said, they add important insights on the lived experiences of volunteers and to debates concerning their roles within the police. According to Constabulary figures, the total of 313 PSVs contributed an average of 2.8 hours each during July 2016, a total of 879 hours. This compared to 502 special constables who contributed on average 21.6 hours each during July 2016, a total of 10,842 hours. At the same time Lancashire Constabulary also had 350 Police Cadets. Their precise contribution is not known (Millie, 2016).

Regarding the Constabulary's 313 PSVs, 57 percent were female and 43 percent male. This compared to the 2011 Census figure for Lancashire of 51 percent female and 49 percent male. Of those interviewed, seven were female and nine male. In terms of age, four of those interviewed were aged 25-49, three were 50-64 and nine were aged 65 and over. This older age profile reflected the profile of PSVs found across the constabulary. In July 2016, 17 per cent of PSVs were aged 18-24, 32 per cent age 25-50, 23 per cent 51-65 and 28 per cent 66 and over. By comparison, according to 2011 census figures, just 23 per cent of the county's population was aged 65 plus $^{4}$. In terms of ethnicity, those volunteering to be PSVs were broadly similar to the county's ethnic breakdown. For instance, 84 per cent of Lancashire Constabulary's PSVs were White British (July 2016 figures), compared to a 2011 census figure for Lancashire of 90 per cent. As for the PSVs that were interviewed, 13 were White British, two British Pakistani and one Chinese.

\section{What PSVs do and their motivations for volunteering}

The roles that PSVs undertake are diverse including almost anything from community road watch to corporate communications, emergency planning, vehicle maintenance, or monitoring CCTV and Automatic Number Plate Recognition (ANPR) systems (Unison, 2014; Bullock, 2017). The 16 PSVs that were interviewed were actively involved in Police Cadet leadership, complaints resolution, community road watch, writing a community newsletter, administration, early action, restorative justice, work with vulnerable victims, auditing, crime trend analysis, role play for recruits, foreign language helplines, survey research, voluntary work in a police sports and social club, and neighbourhood team support. Others were independent custody visitors, independent animal welfare lay visitors, and members of various advisory groups. It seemed the only limitation on what PSVs could do was their lack of police powers, although as noted, at the time of writing this situation was changing, and is explored later in this article.

Whilst some paid officers may query why anyone would work for the police for free, recent research into the Special Constabulary has suggested three main motivations for volunteering (Hieke, 2018). These are instrumental career-driven motivations for those interested in future 
paid employment with the police (or elsewhere), self-oriented motivations relating to personal development, and other-oriented altruistic motivations characterised by wanting to give something back or to help the community. A dominant instrumental motivation for special constables is to improve their CV before applying to become a regular officer (Pepper, 2014; Pepper and Wolf, 2015; Britton and Callender, 2018; Hieke, 2018; Millie, 2018). Research into the unique VPCSO development in Lincolnshire found similar careerdriven motivations, with volunteering seen as a "foot in the door" of policing (Strudwick et al., 2017: 6). In the context of budget cuts some forces have only taken applications for 'regulars' from the ranks of the Special Constabulary and, as such, career-driven motivations for volunteering as a special constable (or as a VPCSO in Lincolnshire) are entirely logical. The situation for PSVs is somewhat different, although some younger applicants in Lancashire did have a career in the police in mind. For instance, for one 27 -year-old male:

Well I always wanted to be in the police service since I was a kid. And, obviously I had health problems, innit. So I thought okay, I can't get in straight away, let's get them dealt with. Once I was free I thought ok, I'd become a volunteer. I always wanted to be a police officer no matter what, I thought okay, because I'm working I just can't commit full time, but I thought with the volunteer side I gain some experience and slowly, slowly work up (M21).

At the time of the interview, this respondent was volunteering as part of a community road watch scheme ${ }^{5}$. Alternatively, many applicants had already had their careers and were searching for something to do post-retirement. According to F12, aged 69, "I can't sit at home and do nothing". Similarly F1, who was 66 when interviewed, stated "I retired, I suppose, two years ago now, but because I've always been very, very busy, I was very, very bored.” According to F3 (aged 70), volunteering for the police appealed,

... because I'd taken early retirement, and I wanted to fill my time. Tried one or two things, didn't like them, didn't enjoy them, looked round for something that would challenge me, that would fill my time, that would give me satisfaction, for which I could contribute, because I want to give back. I really, sincerely think you give back.

This respondent was expressing a combination of self-oriented motivation ("I wanted to fill my time") and other-oriented altruism ("because I wanted to give back"). For some volunteers their interest was more specific. For instance, for one Chinese volunteer in her forties, she became a PSV as it was an opportunity to help her community by working on a Chinese language police helpline. For a 68-year-old PSV his interest was in sports coaching:

I got asked by an inspector 'would I be interested in teaching youngsters?' I do sport, I teach boxing ... and he was a member of my club, and he asked me, or hinted, 'would I like to help or see these younger police cadets and do a bit of sport with them?' And that is how it started, it just snowballed from there really. (M15)

In summary, most volunteers could be seen to gain self-oriented and other-oriented altruistic satisfaction from their volunteering; as one PSV in his 70s put it: 
...it's not been done entirely for altruistic reasons, I mean I want to see, I want to give something back to the community, the sort of standard model answer you would give at interview, you're saving the world and doing good. It is also selfish motives in that I'm retired and I want something stimulating and rewarding to do. So I gain out of it then in two ways; I can give something back to the community and I can also get some personal satisfaction out of doing what I do. (M19)

\section{The lived reality of being a PSV}

All respondents were asked about their experiences of being a PSV. In the first instance they were asked about the process of becoming a PSV. Whilst some found the vetting process difficult and slow, most could understand why various checks were needed before they could be taken on. Once past vetting most had positive things to say about being a PSV. For instance, for one PSV in her 50s, it is, "really interesting; it gives me another avenue to pursue, potentially, for a career" (F24). She explained her enjoyment of volunteering as follows: "I just love meeting new people. I love getting involved in different things. I just find it really fascinating that there's different diverse elements to the volunteering. ... I get a sense of pride out of it. You know, if someone asks me, 'what do I do?' I love telling people what I do".

For another PSV, this time in her 70s, (F25) she enjoyed volunteering as it made her feel useful. A twenty-year-old PSV (F11) enjoyed the flexibility of volunteering, whilst another in his 60s who helped with the Police Cadets enjoyed seeing positive change in young people. According to a PSV in her 70s (F3), "I get a lot of satisfaction from it, inasmuch as I feel very much appreciated, I'm challenged in what I do." That said, a PSV in his 60s who volunteers for the community road watch claimed he did not particularly enjoy the volunteering, but did it for the perceived benefits, “...it keeps the speeds down, and it reduces, hopefully, the death off the road" (M2).

All were asked their views on the role of the volunteer within the police. Most saw themselves as having a supporting role to regular officers, as clearly suggested by the title 'Police Support Volunteer'. In fact, this view was also shared by many of the special constables who were interviewed as part of the wider study (Millie, 2018). For instance, according to F1 (age 66), her job as a PSV was, "to help save police time, to enable them to do their role". Similarly, for F10 (age 33), the aim of her volunteering was to, "work alongside staff and help them to do what they are doing, to support and assist them". Furthermore, according to a 68-year-old male volunteer (M2): "I think the role of the volunteer is to assist ... from a very behind the scenes position, in what mundane duties that the police officers wouldn't particularly want to do as part of their role". A similar position was taken by a female volunteer in her 70s (F3):

Purely as a support, and enhance, and enrich, and provide skills, offer skills that will embellish what they do, but just to help them to do what they do. And perhaps, I'd like to think, in some ways, at times, I've altered the way they do things, or I've made 
suggestions. I mean, they are open to suggestions, a lot of the people I've worked with.

The volunteer is supportive, but also subordinate to regular officers and paid civilian staff, stepping in to do the jobs that others either do not want to do, or do not have the time for. However, it is arguable that volunteers ought to have higher standing, especially in light of the fact that two objectives of taking on volunteers are to help improve police legitimacy within communities, and to provide a bridge between the police and the communities they serve (NPIA, 2008; Bullock, 2014; Millie, 2016). Such objectives are less likely to be fulfilled if the community volunteers are always of a lower status than police employees.

With this in mind it is worth noting the experiences that volunteers bring with them and accrue once volunteering for the police. In terms of policing experience, there was a very wide range among the respondents, with one having just four months experience, whilst another had volunteered for the constabulary for 44 years, first as a special constable for over 30 years and then as a PSV assisting with administration (for 10 years), community road watch (for six years) and the Police Cadets (for three years). This kind of policing experience should not be underestimated; but the main benefit to the service is that volunteers bring with them non-policing professional experiences and skills that are transferrable to a policing environment. The occupations of PSVs (or former occupations for those volunteering postretirement) tended to be white-collar professional. For instance, among those interviewed were a financial consultant, company director, lecturer, teacher, and a tax inspector. Some work may be needed in attracting greater diversity of social backgrounds, especially if part of the aim of having volunteers is to improve community relations. That said, other occupations were represented, including a mental health support worker and one PSV who also worked in a private prison.

According to the College of Policing (undated, b), the benefit of utilising volunteers is the "extensive pool of skills, talents, experience and local knowledge" that they bring with them, and at Constabulary level, attempts are made at matching skills to volunteering vacancies. Many of the volunteers that were interviewed were keen that their particular skills were used. For instance, a 70-year-old volunteer (F3), whose background was in further and higher education, stated that "I'm looking for challenges, I'm looking for work that complements my skills". She achieved this through, among other things, membership of a constabulary Independent Training Advisory Panel. Yet, a finding that managers of police volunteers might also note is that some volunteers would rather do something that is completely different to their existing skillset, to have the challenge of something new. According to one recently retired volunteer (age 66) who previously had her own business, had been a mortgage consultant and had also worked in sales, "I needed something which would utilise your brain, but also perhaps looking for something different than perhaps I'd done before" (F1). At the time of the interview she was volunteering as a police complaints facilitator, a task that uses her broader skillset but was not necessarily directly related to her previous experience. At the other end of the age spectrum, a 29-year old PSV noted how he enjoys: 
... putting my people skills into perspective, perhaps building up new skills ... and just working in something completely different, because I've mainly worked in education and teaching, and doing this, and this, and this, so it's actually nice to use a completely different skillset. (M4)

This particular PSV was volunteering in restorative justice and early action support. It seems that PSVs like the flexibility of working in areas that interest them. These may be in areas that utilise their skills and experience, but this is not always the case with some actively looking for other challenges.

The respondents were also asked why they have stayed as a volunteer. For one female volunteer in her 60s, "as long as they'll have me ... I just like to help" (F12). According to a male volunteering in his 50s, "I find it rewarding" (M23). Others saw the volunteering as suiting their current circumstances. For one 52-year-old, "it suits what I want to do at the moment, I need the volunteering" (F24). For a 68-year-old male, "Well for the moment I'm enjoying what I'm doing, I'm enjoying it" (M15). There is general enthusiasm among the volunteers, but they may be a self-selecting group as those less enthusiastic may not have considered volunteering in the first place, or if they had, they might have dropped out.

With this in mind the quality of supervision becomes an important issue. For the most part PSVs were positive about their supervision, although it depended on the personnel involved. For instance, one PSV in his 70s (M8) was supervised by a Community Beat Manager who he described as a "lovely man, you know, a really nice chap". However, he added that, "it would be nice to have a meeting with him, you know. We did say that we'd start having meetings but they never really, they never really took off'. As noted by a volunteer in his 50s (M23), a lack of feedback could also become an issue:

The only negative is the lack of feedback. You would expect to get feedback sooner. The positives have been, everybody cares, you send an email, you get a response straight away. It's a really good team to work for, but you do feel a little bit left out of it.

M16 (age 74) went further in claiming, "Without being negative, there's no supervision". Despite this, most had positive experiences of supervision; as M4 (age 29) stated, "Early action is very well supervised, in the sense that the person who leads it is easily contactable". The willingness of others to assist the volunteers was a common theme, that "everybody seems to pull together" (M15, age 68).

Whilst some PSVs had little communication with regular officers, those that did tended to have good relations. For instance, For F12 (age 69), when working with regulars, "I'm always welcomed. I don't feel intimidated whatsoever". Similarly, for F10 (age 33), regular officers, "will always be thankful and appreciative of the work we do. And it is good to hear that from them". According to one male PSV in his 60s, "if you're stuck, they'll help you with anything. As will any police officer - I mean, I just call into the canteen” (M2). 
At a time of budget cuts it might be assumed that regular officers would see volunteers as a threat. According to the respondents in this study the contrary is true. It seems regulars are appreciative of the help available, no matter what form it comes in. It is possible that a different picture would emerge if regular officers were interviewed; however, if the volunteers are correct, then volunteer-regular issues are less than might be imagined. According to M8 (age 76), "Oh, can't fault it, you know they are excellent, you know, whatever rank. I have never had a problem there, they are always very civil, very pleasant".

The PSVs' relations with other police staff and with other volunteers were also broadly positive. Regarding relations with other volunteers, as M16 (age 74) put it, "we've always got on well, we've had a laugh". Similarly, according to M4 (age 29):

with regards to the volunteers, we get on great because we're all, like I say, we're all likeminded. The beauty of it is, you come from different backgrounds, different experiences, but you're all also more motivated by the reason for helping the others out.

So far it seems that most volunteers have good relations with colleagues, they are broadly positive of their supervision and enjoy what they do. This is very encouraging for volunteer managers; yet there are some areas that require improvement. When asked whether there was anything they would change about their volunteering experience, some volunteers stated that they felt under-used. This was an issue identified in an earlier 2014 survey commissioned by Lancashire Constabulary, where one respondent stated, "I feel under-used. All I can say is "use it or lose it"" (Lancashire Constabulary, 2014; Millie, 2016). This was still a concern for the respondents in the current study; as one PSV in his 50s who volunteers for police complaints resolution put it, "it's very interesting [but] it's a bit intermittent" (M23). Similarly, for another volunteer for police complaints resolution (M19, age 73), there is a "... lack of allocation of casework, I think people are drifting away". There was clearly an issue within this particular strand of volunteering; as F1 (age 66) observed, “...the main thing we've found is that we're not kept up to date with events relating to these complainants. So, we end up sort of having to contact people to say, 'Has anything happened?'”

Taking on volunteers is one thing, but having the organisational infrastructure and sufficient personnel to manage volunteers is another. For instance, one PSV working with a restorative justice scheme complained that after initial training for the scheme, "I was all buoyed up for it then, as I say, some staff through sickness or whatever, they left and you lose the momentum. I'm still keen to be involved, but you do need to be kept informed." (M16, age 74).

\section{PSVs and police powers}

In addition to being under-used or not being kept informed, many of those interviewed were also concerned about the prospect of being given certain police powers. At the time of the study in 2016, PSVs did not hold any police powers. However, since then the 2017 Policing and Crime Act (s.38) has introduced the ability for chief officers to designate powers to Policing Support Volunteers (PSVs) and Community Support Volunteers (CSVs) (Home 
Office, 2016a; 2016b; 2017; Rathmell, 2017). It is the first time that any powers have been available for non-warranted and non-employed volunteers. The newly badged CSVs are intended to be a volunteering equivalent in status to the already existing and paid Police Community Support Officers (PCSOs) (Home Office, 2016a: 7) - referred to as CSOs in the legislation - and have much in common with the existing Lincolnshire VPCSO scheme. The aim for both PSVs and CSVs is to, "better enable chief officers to make the most efficient and effective use of their workforce by giving them the flexibility to confer a wider range of powers on police staff and volunteers" (Home Office, 2017). Whilst the draft Bill was being considered, the Police Federation and police staff union saw this as mission creep (Police Federation, 2016).

Under the 2017 Policing and Crime Act chief officers can designate PSVs with any policing power, except for a core list of powers that are still reserved for warranted officers (Rathmell $(2017)^{6}$. They are excluded from: power of arrest; stop and search powers; performing the function of a custody officer if a custody officer is not available; powers associated with particular police rank (such as decision making powers of Chief Inspector and above); powers under the 2000-2015 Terrorism Acts; powers under the 1911-1989 Official Secrets Acts; and certain powers under the 2016 Investigatory Powers Act. Whilst volunteers cannot carry firearms or Tasers, they may carry CS or PAVA spray if appropriate (Rathmell, 2017).

In the current study, the idea of giving any powers to volunteers who are not special constables received a mixed reception from the PSVs. Some were in favour. For instance, according to a 33-year old volunteer with community road watch (F10), "I'd love to have the appropriate training and I think, yes, I would like to have a bit more power". Similarly, for another volunteer with community road watch, this time in his twenties (M21), "Brilliant. I could do with a few powers." Yet others were not in favour of having any powers at all and saw their role as something quite different to a warranted officer. Respondent F5, who was in her forties, claimed, "I don't like that idea ... some power just belongs to policemen". This volunteer was only involved with a community helpline. Presuming F5 did not take on any other volunteering duties, she would not likely be given any powers. M8 (age 76) was similarly unenthusiastic in stating, "you couldn't have a volunteer, for example, stopping a vehicle for speeding, I mean if they had a speed gun, you know, like waving them down, I wouldn't agree with that". Again, given his current role editing a neighbourhood policing newsletter he himself is unlikely to be given powers. Respondent M2, who was in his sixties, was also strongly against the idea. He volunteered as part of community road watch and could conceivably benefit from having relevant powers to prosecute speeding motorists. Yet, according to M2, "I think that is the most absurd idea that the government's ever come up with, because you're just putting people at risk". He further stated that,

... if they said now, 'We're going to give volunteers all these powers', that's me finished tomorrow. Yeah, I'm just not interested in anything like that, and I think it's wrong. I think it's stupid. (M2)

Some respondents recognised a need for re-training should they get powers, and possibly also being re-interviewed, "to see whether they have got the ability to hold that power and utilise 
it and do it properly" (M15, age 68). Similarly, for a 73-year-old volunteer with the Professional Standards Department:

... we haven't gone through proper recruitment procedures, we haven't been given proper training, so we're not fit to assume the responsibilities of police officers, and if that being the case I don't think we should be given police powers, it wouldn't be appropriate. (M19)

So, whilst a few welcomed the possibility of powers, other PSVs were against the idea. In many ways there are distinct advantages to not having powers. For instance, according to a PSV in her twenties (F4), who volunteers in early action and restorative justice, it makes sense to be able to go to clients and say that she is something different to the police. That said, she was open to at least consider possible benefits of powers:

... the difficult thing for volunteers having powers is that, if I'm going in to someone and saying, 'Actually, although I'm a volunteer, I don't work for the police, I'm not paid by the police', it's what I usually say; but then all of a sudden, I've got the power to take your phone for evidence, because you've done this, I've got the power to arrest you, ... But then, in one sense, could powers help me to do my particular role?

In other research conducted prior to the new legislation on Lincolnshire's unique VPCSO scheme (Strudwick et al., 2017), volunteers recognised their lack of powers, but they "still felt that they could function successfully without these" (p.11). That said, some of Strudwick et al's respondents saw a need for some powers so that they could do the same job as their paid equivalents. There are perhaps occasions when giving limited powers to volunteers including PSVs - could conceivably be useful. For instance, writing whilst Home Secretary, Theresa May (Home Office, 2016b) stated in this context that, "we want to encourage those with skills in particular demand, such as those with specialist IT or accountancy skills, to work alongside police officers to investigate cyber or financial crime". Yet, if constabularies wanted to give powers to volunteers with specific skill sets, then they could already do this through the framework of the Special Constabulary.

This is an important distinction. The PSVs in this study did not necessarily see themselves as 'the police' and instead offered something different. As a PSV in her twenties noted, "I don't work for the police, I'm not paid by the police" (F4). Similarly, a 70-year-old PSV made a clear distinction between the police volunteer and the paid professional: "If I work for you, you're employing me, and I'm stuck with you. As a volunteer, I work with you, and if I don't like what I get, I'll walk away" (F3). At the time of writing, the long-term ramifications of the 2017 Policing and Crime Act were yet to unfold, but it will be important to take PSVs' views on board - that they are working in partnership with the police, rather than working for the police. 


\section{Conclusions}

Whilst there is a growing body of literature on those who volunteer as special constables, less is known about non-warranted volunteers. This article has contributed to addressing this omission by considering the lived reality of being a Police Support Volunteer (PSV) within Lancashire Constabulary. It is possible that those who volunteer for different constabularies and in other national contexts have different experiences, and so further comparative research would be beneficial. That said, the research reported here adds important evidence, which, if taken alongside other emerging research on PSVs (such as by Britton and Callender, 2016; Bullock, 2017; and Callender et al., 2018), helps to paint a picture of this important area of police volunteering.

The context to the research was a police service that needed to work on a reduced budget. At the same time, the UK government promoted responsibilisation through agendas centred on active participation and localism. The result was that volunteering was promoted as a way to engender responsible citizenship and to provide services that the police could not cover at a time of austerity. What the Lancashire research found was that those who volunteered as PSVs came from a wide range of ages, but were often post-retirement looking for something useful and interesting to do. They were driven by a combination of self-oriented motivation in wanting to do something interesting and other-oriented altruism in that they wished to give something back to the community. A few of the younger PSVs were also motivated by a desire to improve their CVs, including those who wished to apply to become regular officers in the future. The age profile of PSVs was slightly older than the profile for the county, with a number attracted to volunteering post-retirement. However, PSVs (including those interviewed) were broadly reflective of the county's ethnic composition. That said, more work in attracting Black and minority ethnic volunteers in specific areas would still be beneficial; as one 33-year-old British Pakistani noted, part of her motivation for being a PSV was to 'build bridges':

... a lot of people from a BME community, maybe because they have had bad experience with the police, or staff, I'm not 100 percent [sure], they are really reluctant. So it would be good for the public to see, ok, this police staff, police volunteers who are BME as well. Let's start building bridges, because it is about partnership working with the community and the staff. (F10)

The PSVs in Lancashire also tended to be from white-collar middle-class backgrounds, including a range of financial consultants, company directors, lecturers and teachers. Whilst some are from other social backgrounds, work is needed to promote the benefits of volunteering to a wider audience. This is an important consideration, as stated objectives of the 'Citizens in Policing' programme are to build social capital and to contribute to policing by consent - with volunteers acting as a bridge between the police and the community. According to the College of Policing (undated, a): 
Embracing and developing 'citizens in policing' provides an excellent opportunity to not only increase additional capabilities, but also to build social capital and ensure that the service continues to successfully police with our communities' consent.

The PSVs were generally enthusiastic and brought with them a range of experiences. For instance, as noted, one respondent had already been volunteering for the constabulary for 44 years. Such policing experience should not be overlooked. Many also brought skills from outside employment that were useful for police managers. A large number wished to use the skills they already had, but within the policing setting and, with this in mind, a skills analysis of new volunteering recruits is useful. However, it should also be noted that a proportion of volunteers wished to do something completely different to their day job, or to their previous occupation. Constabularies may find it useful to take on volunteers with specific skills to match their current needs; yet flexibility is required to allow volunteers opportunities to explore other areas and have the challenge of something new. Lancashire Constabulary advertises volunteering opportunities online which makes the volunteers' task of finding interesting roles and opportunities a lot easier.

At a time of budget constraint it might be assumed that regular officers will see volunteers as a threat. If the findings from this study are generalizable, then it seems that regular officers are in fact appreciative of what volunteers can contribute. Lancashire Constabulary's policy of seeking union approval for new volunteering posts may be beneficial here. It would be interesting to hear what regular officers and other paid police personnel have to say, both in Lancashire and elsewhere, but this would have to be in a future study. Whilst PSVs were complementary of their policing colleagues they were also broadly positive of their supervision, although this depended on the specific person involved. Some respondents experienced poor supervision and complained of not having enough to do, or of not being kept informed of developments in their particular area of volunteering. By not paying attention to such important details, good will may be lost with a detrimental impact on policecommunity relations and on future recruitment. Research has found that special constables are most often recruited by word-of-mouth from those already volunteering (Mirrlees-Black and Byron, 1994; NPIA, 2010; Bullock and Millie, 2018b). It is likely that the same is true for PSVs.

Along with not being given enough to do, or not being kept informed, a further concern for some volunteers was the prospect of being given certain police powers. Whilst some were in favour, others saw the role of the PSV as something quite different and that powers would not be welcomed. Most PSVs saw their role as being in support of their colleagues. Volunteers were doing the jobs that others did not have the time for, or did not want to do. But in a context where the police wish to make improvements to community-police relations and where volunteers are assumed to act as a bridge between the two, such subordination is challenged. Police services are traditionally highly hierarchical organisations and unpaid, unwarranted and non-uniformed volunteers are likely to be at the bottom of this pecking order. Yet, part of the motivation for having people volunteer as PSVs is to attract those with the specific skills that the police need, but do not necessarily have. It should be remembered that, while there are various self-oriented and other-oriented benefits for the volunteer, the police 
service also needs the volunteer to do a role that it cannot do by itself - which ought to put the volunteer in a position of strength. If taken seriously, an equality of status for volunteers would have important implications for our practical and theoretical understanding of policing; although as Bullock (2017) has highlighted, suitable systems of accountability, oversight and redress would be required for volunteers. Hopefully this has been addressed within the 2017 Policing and Crime Act (s. 41) with volunteers now included within complaints and disciplinary procedures. With this in mind, the volunteer deserves to have adequate training and supervision, and be kept informed of developments in their area. The volunteer should also have sufficient freedom - within reasonable bounds of what is appropriate in terms of security clearance, suitability and ability - to explore areas of volunteering that interest them, even if these are outside of their previous experience and specific skills.

It is encouraging that, for those included in this study, the experience of being a PSV was broadly positive with discernible benefits for the volunteer and for the constabulary. Yet, as Bullock (2017) has noted, the introduction of PSVs has occurred with little scrutiny or debate. For Bullock, there are organisational gains from voluntary involvement, but public interest benefits need examination and the management and support of volunteers needs further consideration. This article has highlighted the need for adequate training and supervision. In this context it should be remembered that, as one of the respondents observed, PSVs work with rather than for the police. If taken for granted, or not given enough to do, then the volunteer can simply walk away. Furthermore, the unique position of the nonwarranted PSV within the 'police family' ought to be protected. As the implications of the 2017 Policing and Crime Act unfold, a lack of enthusiasm for powers among some of the PSVs may mean any roll out of powers could act as a threat to the future of non-warranted volunteers.

\section{Acknowledgements}

The research was conducted independently of the Constabulary, but would not have been possible without their assistance. The author is grateful to all who agreed to be interviewed, and especially the PSVs who worked alongside the author as part of the interviewing team.

\section{Disclosure statement}

No potential conflict of interest was reported by the author.

\section{References}

Banton, M. (1964) The Policeman in the Community, London: Tavistock.

Brodeur, J-P. (2010) The Policing Web, Oxford: Oxford University Press. 
Bennett, J. (2008) 'They hug hoodies, don't they? Responsibility, irresponsibility and responsibilisation in Conservative crime policy', Howard Journal of Criminal Justice, 47(5) $451-469$.

Bennett, T. (1990) Evaluating Neighbourhood Watch, Aldershot: Gower.

Britton, I. and Callender, M. (2016) 'Citizen Involvement in Policing - A critical but underresearched aspect of policing', Social Policy Association Conference, Belfast, 4-6 July. Available at: http://nectar.northampton.ac.uk/8594/1/Britton\%20and\%20Callender\%20\%20Citizen\%20Involvement\%20in\%20Policing.pdf [Accessed 3 October 2017]

Britton, I. and Callender, M. (2018) 'Strategic direction and leadership of the Special Constabulary', in K. Bullock and A. Millie (eds.) The Special Constabulary: Historical Context, International Comparisons and Contemporary Themes, Abingdon: Routledge. 149168.

Brudney, J. (1999) 'The effective use of volunteers: Best practices for the public sector', Law and Contemporary Problems, 62(4) 219-255.

Bullock, K. (2014) Citizens, Community and Crime Control, Basingstoke: Palgrave Macmillan.

Bullock, K. (2017) 'Shoring up the 'home guard'? Reflections on the development and deployment of police support volunteer programmes in England and Wales', Policing and Society, 27(4) 341-357.

Bullock, K. and Millie, A. (2018a) (eds.) The Special Constabulary: Historical Context, International Comparisons and Contemporary Themes, Abingdon: Routledge.

Bullock, K. and Millie, A. (2018b) 'Introduction', in K. Bullock and A. Millie (2018a) (eds.) The Special Constabulary: Historical Context, International Comparisons and Contemporary Themes, Abingdon: Routledge. 1-14.

Callender, M., Pepper, M., Cahalin, K. and Britton, I. (2018) 'Exploring the Police Support Volunteer experience: Findings from a national survey', Policing and Society. Doi. 10.1080/10439463.2018.1432613.

Cameron, D. (2010) Big society speech, 19 July, Available at: http://webarchive.nationalarchives.gov.uk/20130102234209/http://www.number10.gov.uk/ne ws/big-society-speech/ [Accessed 23 October 2017]

College of Policing (undated, a) Citizens in Policing, Webpage, Available at: www.college.police.uk/What-we-do/Support/Citizens/Pages/default.aspx [Accessed 21 July 2017]

College of Policing (undated, b) Creating a Business Case, Webpage, Available at: www.college.police.uk/What-we-do/Support/Citizens/PSVs/Pages/Creating-businesscase.aspx [Accessed 14 August 2017]

Crawford, A. (2014) 'The police, policing and the future of the "extended policing family", in J.M. Brown (ed.) The Future of Policing, Abingdon: Routledge. 173-190.

Crawford, A. and Lister, S. (2004) The Extended Policing Family: Visible Patrols in Residential Areas, York: Joseph Rowntree Foundation. 
Dobrin, A. (2017) 'Volunteer police: History, benefits, costs and current descriptions', Security Journal, 30(3) 717-733.

Garland, D. (2001) The Culture of Control: Crime and Social Order in Contemporary Society, Oxford: Oxford University Press.

Gill, M. and Mawby, R. (1990) A Special Constable: A Study of the Police Reserve, Aldershot: Avebury.

Hieke, G. (2018) 'General perspectives on volunteer motivation within the Special Constabulary', in K. Bullock and A. Millie (eds.) The Special Constabulary: Historical Context, International Comparisons and Contemporary Themes, Abingdon: Routledge. 8093.

HM Treasury (2010) Spending Review 2010, Cm 7942, London: TSO.

Home Office, (2016a) Reforming the Powers of Police Staff and Volunteers: Summary of Consultation Responses and Proposals for Legislation, London: Home Office.

Home Office (2016b) Police volunteers to be given powers without taking on role of special constable, News Story 20 January 2016. Available at: www.gov.uk/government/news/policevolunteers-to-be-given-powers-without-taking-on-role-of-special-constable [Accessed 26 July 2017]

Home Office (2017) Policing and Crime Bill receives Royal Assent, News Story 31 January 2017. Available at: www.gov.uk/government/news/policing-and-crime-bill-receives-royalassent [Accessed 26 July 2017]

Kindon, S., Pain, R. and Kesby, M. (2007) 'Introduction: Connecting people, participation and place', in S. Kindon, R. Pain and M. Kesby (eds.) Participatory Action Research Approaches and Methods: Connecting People, Participation and Place, Abingdon: Routledge. 1-7.

Lancashire Constabulary (2014) Lancashire Constabulary Police Support Volunteer Scheme Volunteer Survey 2014, Internal Document, Preston: Lancashire Constabulary.

Leon, C. (1991) Special Constables: An Historical and Contemporary Survey, Unpublished $\mathrm{PhD}$ thesis, Bath: University of Bath.

Leon, C. (2018) 'Special constables and the birth of 'regular' policing', in K. Bullock and A. Millie (eds.) The Special Constabulary: Historical Context, International Comparisons and Contemporary Themes, Abingdon: Routledge. 28-45.

Millie, A. (2011) 'Big society, small government: The British coalition government and tackling anti-social behaviour', Crime Prevention and Community Safety, 13(4) 284-287.

Millie, A. (2012) 'Police stations, architecture and public reassurance', British Journal of Criminology, 52(6) 1092-1112.

Millie, A. (2013) 'The policing task and the expansion (and contraction) of British policing', Criminology and Criminal Justice, 13(2) 143-160.

Millie, A. (2016) Volunteering within the Police: Experiences of Special Constables and Police Support Volunteers, Edge Hill University, Ormskirk. 
Millie, A. (2018) 'The beliefs and values of police volunteers', in K. Bullock and A. Millie (eds.) The Special Constabulary: Historical Context, International Comparisons and Contemporary Themes, Abingdon: Routledge. 105-117.

Millie, A. and Bullock, K. (2012) 'Re-imagining policing post-austerity', British Academy Review, Issue 19, 16-18.

Millie, A. and Jacobson, J. (2002) Employee Volunteering and the Special Constabulary: A Review of Employer Policies, London: The Police Foundation.

Mirrlees-Black, C. and Byron, C. (1994) Special Considerations: Issues for the Management and Organisation of the Volunteer Police, Home Office Research and Planning Unit Paper 88, London: Home Office.

Neuberger, Baroness (2009) Volunteering Across the Criminal Justice System, London: The Cabinet Office.

NPIA (2008) Special Constabulary National Strategy Implementation Advice, London: NPIA.

NPIA (2010) Special Constabulary Recruitment Marketing and Retention Surveys: Report of Findings - July 2010, London: NPIA. Available at: www.college.police.uk/What-wedo/Support/Citizens/Special-

Constabulary/Documents/Special_Constabulary_report_of_findings_SEP_2010.pdf [Accessed 4 August 2017]

O’Neill, M. (2017) 'Police community support officers in England: A dramaturgical analysis', Policing and Society, 27(1) 21-39.

Pepper, I. (2014) 'Do part-time volunteer police officers aspire to be regular police officers?', Police Journal: Theory, Practice and Principles, 87(2) 105-113.

Pepper, I. and Wolf, R. (2015) 'Volunteering to serve: An international comparison of volunteer police officers in a UK North East Police Force and a US Florida Sheriff's Office', Police Journal: Theory, Practice and Principles, 88(3) 209-219.

Police Federation (2016) Giving volunteers more police powers is 'mission creep', 16 March 2016. Available at: http://www.polfed.org/newsroom/3223.aspx [Accessed 7 August 2017]

Rathmell, A. (2017) 'Power to the police staff? Big changes to police powers', Serjeants' Inn Chambers UK Police Law Blog, 28 February. Available at:

www.ukpolicelawblog.com/index.php/9-blog/112-power-to-the-staff-big-changes-todesignated-powers [Accessed 26 July 2017]

Seth, R. (1961) The Specials: The Story of the Special Constabulary in England, Wales and Scotland, London: Victor Gollancz.

Strudwick, K., Jameson, J. and Rowe, J. (2017) 'Developing volunteers in policing: Assessing the Potential Volunteer Police Community Police Officer', Policing: A Journal of Policy and Practice, Advance Access.

Tomczak, P. (2016) The Penal Voluntary Sector, Abingdon: Routledge. 
Unison (2014) 'Home Guard' of the Police Support Volunteers to Fill in for Police Cuts, London: Unison, Available at: www.unison.org.uk/content/uploads/2014/11/TowebUNISON-report-on-Police-SupportVolunteers2.pdf [Accessed 7 August 2017].

Washnis, G.L. (1976) Citizen Involvement in Crime Prevention, London: Lexington Books.

Wolf, R., Holmes, S.T. and Jones, C. (2016) 'Utilization and satisfaction of volunteer law enforcement officers in the office of the American sheriff: An exploratory nationwide study', Police Practice and Research, 17(5) 448-462.

\footnotetext{
${ }^{1}$ See also Millie $(2016 ; 2018)$

${ }^{2}$ It is possible that only those with sufficient political and social capital were able to take on this challenge (Millie, 2011).

${ }^{3}$ PCSOs were introduced with the 2002 Police Reform Act as uniformed, paid civilian members of police staff who are non-warranted but hold some limited powers (see e.g. O’Neill, 2017).

${ }^{4} 2016$ volunteering data made available to the author, 2011 Census data from www.nomisweb.co.uk

${ }^{5}$ Elsewhere this has been labelled as Community Speedwatch. Volunteers are trained in using speed detection equipment and deployed to identify speeding motorists. Currently, motorists caught speeding in this way can only be sent a warning letter. See: www.communityspeedwatch.co.uk [Accessed 5 October 2017]

${ }^{6}$ Under the 2017 Policing and Crime Act, CSVs have the same powers as CSOs (or PCSOs) and have the power to: issue Fixed Penalty Notices; require names and addresses; search for and seize alcohol and tobacco; seize and detain controlled drugs and psychoactive substances; the power to detain pending arrival of a constable (and to search those detained); and the power to use reasonable force (Rathmell, 2017; 2017 Policing and Crime Act, Schedule 3c, 1-11).
} 